Wasik Magdalena. The role of the nurse in improving the quality of healthcare. Journal of Education, Health and Sport. 2020;10(4):68-74. eISSN 2391-8306. DOI http://dx.doi.org/10.12775/JEHS.2020.10.04.008

https://apcz.umk.pl/czasopisma/index.php/JEHS/article/view/JEHS.2020.10.04.008

https://zenodo.org/record/3747604

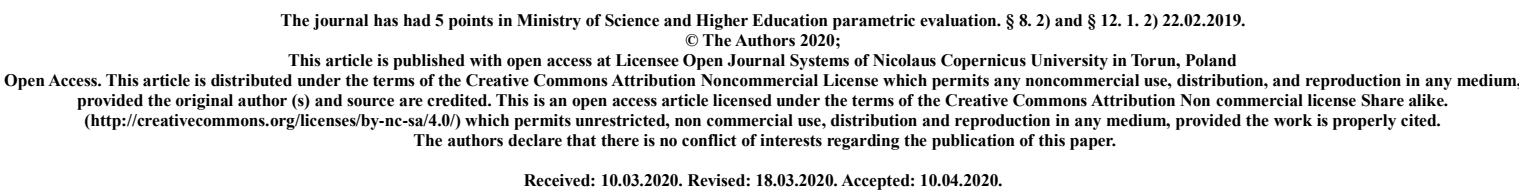

The role of the nurse in improving the quality of healthcare

\title{
Magdalena Wasik
}

ORCID: orcid.org/0000-0003-2249-8498

e-mail: magdawasik95@gmail.com

Collegium Medicum, Doctoral School of the Jan Kochanowski University in Kielce aleja IX Wieków Kielc 19A, 25-317 Kielce

\section{Abstract \\ Introduction}

The nurse provides medical care for the patient, including nursing, administering medicines and performing injections. She assists the doctor in the process of diagnosis and treatment. The definition of this profession changes as a result of the development of science and increasing expectations of health care. The development of this profession is evidenced by developed models of nursing, which will focus on the practical application of the acquired knowledge.

\section{Aim}

The aim of this work was to present the tasks and competences of nursing and the role of this profession in improving the quality of patient care.

\section{Material and method}

The paper uses the method of literature analysis. The material used in the paper comes from publications published in a compact form and scientific articles. 


\section{Results}

The review of the collected scientific material showed that nurses have a significant impact on the quality of health care and the functioning of the entire facility. Healthcare institutions belong to organizations in which the quality of services translates into the patient's health and life. Care should therefore be a priority for the entire staff, especially for the nurses who first meet the patient and spend a lot of time with him. Patients expect medical knowledge from nurses first and foremost, but also safety, trust and proper communication.

\section{Conclusions}

In recent years, nursing has been constantly changing, which means that people in this profession have to take various actions for their development. Patient expectations are also changing. Their opinion and satisfaction is important for success. A satisfied patient will surely use the services of the facility again.

Key words: nursing; quality of care; patient

\section{Introduction}

The profession of a nurse is included in the independent medical profession. A nurse is a very important member of the therapeutic team, which carries out many responsible tasks and thus enables greater public access to health care. Nursing is constantly evolving, taking on new roles and competences in order to meet the growing expectations of patients. This profession can be carried out by a person with appropriate qualifications, which he acquired during the course of education and the right to practice the profession. The rules of exercising the profession, obtaining the right to exercise the profession, professional and post-graduate training are described in detail in the Act on Professions of Nurse and Midwife. In order to improve their competences, nurses may participate in various training courses and specialisation courses $[1,2]$.

\section{Nurses' tasks}

The mission of nursing is to help individuals and groups to achieve their mental, physical and social potential in the environment in which they operate on a daily basis. The functions of nurses result directly from the mission and the essence of this profession. It is primarily to assess the needs of patients, plan nursing activities, and determine which tasks require the involvement of other professionals in a particular field [3]. Keeping records of the activities already performed in order to be able to better organize future activities also belongs to the activities of a nurse. It is also respecting the applicable professional, ethical and cultural standards. Prevention and health promotion activities consist in the assessment, recognition and prevention of all activities that threaten health and life [4]. Nurses take an active part in the implementation of health programmes. They educate patients on healthy lifestyle, take care of the sick and perform nursing procedures. They play an important role in preparing patients for independent care during illness or disability. They are an important part of the teams of people who create health policy and participate in research programmes [5]. 
According to the Act of 15 July 2011 on the professions of a nurse and midwife, the profession of a nurse consists primarily of such activities as:

- recognition of health and nursing needs of patients

- planning of all care activities

- providing prophylactic, diagnostic, rehabilitation and therapeutic services on their own within the scope of their competence

- implementation of doctor's recommendations

- deciding on the type of benefits

- promoting prevention and health promotion activities

- providing health education to patients

- directing scientific research on nursing

- managing groups of nurses and midwives

- carrying out continuous professional development activities

- participation in the teaching of the medical professions, if provided for in the training programme

- conducting administrative work consisting in the organisation and supervision of individual health services [6].

The development of the nursing profession is a process that results from the constant need to provide the best possible care for both the youngest groups of people and the elderly. Focusing only on meeting the needs of the patient's illness is insufficient. The World Health Organization emphasizes the importance of treating man as a bio-psycho-social being and understanding that biological, psychological and social factors are involved in the occurrence of the disease and in improving health. Human health can change dynamically, and therefore patients' expectations of medical personnel continue to increase due to the need to meet their needs $[7,8]$.

\section{Defining the profession according to nursing models}

The answer to the needs and problems of patients is to develop models of nursing, which testify to the practical and scientific development of the profession. Changes in the very definition of nursing can also be observed [9].

Florence Nightingale, the founder of modern nursing, has developed a model of community nursing. According to her, a nurse should have not only medical knowledge, but also statistical, administrative, public health, legal or ethical knowledge. She believed that man has a very large impact on the environment and through the changes he makes in it can improve his health. The assumptions of this model can bring benefits only with the cooperation of the whole medical personnel and using the knowledge from the coexisting sciences [10].

According to the Hildegard Peplau interpersonal relationship model, a nurse is a person who professionally performs his duties related to patient therapy to restore his health. She helps the patient to fight fears, concerns about the disease, teaches how to control her behavior and how to deal with problems. In this model, the interdisciplinary of the nurse's profession is emphasized because apart from medical knowledge, the knowledge of psychology or pedagogy is also needed [11]. 
The help directed towards both sick and healthy people is the implementation of the Virginia Henderson model. The author believed that a nurse should improve her skills throughout her life to help the patient in the best possible way. Her definition of nursing has been adopted by the International Council of Nurses as binding worldwide. This model is based on Maslow's theory of needs. The nurse is to act in such a way that the patient becomes independent in the shortest possible time and does not need to be supported in his daily activities. [12].

Another of the models created by Dorothy Ormen emphasizes that nursing is a social service consisting in caring for those who, for various reasons, cannot do it themselves. She distinguished in this model the theory of self-care, self-care deficit and nursing systems. The ability to self-care depends on factors such as age, gender, health status, environmental factors and family situation. Self-care is the activity of every human being undertaken to ensure the best conditions for maintaining health. Self-care deficit occurs when a person is unable to meet their own needs, e.g. as a result of illness, and needs nursing care. It may happen that the patient is able to perform certain activities alone, but he does not have the appropriate knowledge or motivation. In this case, a nursing system called support and education is necessary to be used, which consists in providing such a person with necessary information in a manner adapted to his capabilities, as well as supporting him in every activity. When the patient requires help in every activity, we are talking about a completely compensating or partially compensating system, when this help is only partial [13,14].

Callisa Roy, the creator of the adaptive nursing model, claims that nursing combines scientific and practical features. Nursing activities should also focus on identifying adaptive responses. The role of the nurse is to prepare the patient for a new life situation changed by the occurrence of the disease. It is also important to adapt the family to changes [15].

Each of the presented models of nursing care emphasizes the responsibility of the profession and focuses on the practical application of the acquired skills. The main goal of each of them is to provide the best possible care for both the sick and healthy person. This assistance does not have to concern only the physical sphere, but also the mental sphere [16].

The professional tasks and challenges faced by nurses are closely related to the progress of learning. The biological, psychological, social, philosophical, economic and other sciences containing management and guidance theory work closely with nurses. Interdisciplinary is extremely important, allowing for effective analysis and proper recognition of patient needs $[17,18]$.

\section{Quality in health care}

Monitoring patients' needs is important because it involves providing them with the highest quality care. In the modern world, the term "quality" is very often used both in everyday life and in various publications. This term has been known since ancient times. Nowadays, the definition of quality is very diverse and depends primarily on the area in which it is to be used [19].

Quality is compliance with requirements, it is an activity tailored to the requirements of the market. The term can be defined as the execution of a product or service to meet the expectations of customers. The term can be explained in various ways, taking into account the specificity of a given market. The changes that take place make the customer a quality 
indicator to a large extent. Quality does not only concern the characteristics of a given product or process, but also takes into account all the accompanying activities. Undoubtedly, the main objective of any modern organisation should be quality improvement, especially when it comes to medical institutions [20].

Medical services are characterised by certain basic features which will enable them to be classified as service activities. The first is immateriality, as patients are unable to assess the outcome of treatment before visiting their doctor. The second feature is inseparability. Medical services are performed and received at the same time and cannot take place without the patient or staff. It is also important to involve the patient himself in the treatment process, which enables effective achievement of the intended goal of improving health [21]. The medical service is also irreversible. This means that it is not possible to use it when a predefined deadline expires. Another feature is diversity, which means that the patient is a separate case, therefore the treatment and diagnostics are adjusted by medical personnel individually for each patient [22].

Quality in health care is extremely important because it directly affects the patient's health and even life. One of the most important values in human life is health. When our health deteriorates all the other aspects of our life as well. It is a value thanks to which every person can function properly in society [23]. This enables him to achieve his goals, to follow each day through his previously assigned tasks and to fulfill them. Maintaining good mental and physical condition is also a necessary condition for fulfilling social roles, both in family and professional life [24].

According to the World Health Organization (WHO), quality is the top priority in health care. Each medical institution strives to ensure that the standard of services provided is of the highest possible standard and to fully satisfy the patient. The role of quality is still growing. It is an important element which determines the position of a medical institution on the market. The reason for this is the progressive standardization and treatment of the patient as a person who is in the center of the system. It is extremely important to take an individual approach to each person and to see their needs and the requirements they place on the facility. The competition between the institutions is still growing. The managers of medical centres should be aware of the fact that the awareness of patients, who are increasingly familiar with their rights and expect professional service of the highest quality, has increased [25].

The new tasks and roles that are given to the nurses are due to the changes that are taking place in modern nursing. Quality assurance in medical services is not only about a modern building, the latest equipment and highly qualified medical staff, but also about understanding the patient and proper communication. Quality is not a single action, but a process in which all employees of a given medical facility should be involved. It is also the selection of appropriate means and methods to communicate with the patient, especially if we are dealing with a disease [26]. This is also a difficult situation for the patient's family, which is why he requires appropriate interpersonal skills from the nurse. Choosing the right form of communication adapted to the patient facilitates achieving the desired therapeutic effects. Nurse staff play a key role here, as they form an integral part of healthcare [27]. Communication not only affects the satisfaction of patients with contacts with medical staff, but above all the better effect of treatment. Research confirms that patients expect from healthcare professionals above all professional advice and information tailored to their level 
of knowledge, but they also need support, respect, understanding and empathy. The use of appropriate communication by the staff determines that the patient will use the services of the given facility again $[28,29]$.

\section{Conclusions}

Nursing is a profession that is constantly changing and taking on new roles. The development of this profession is particularly visible in the scope of tasks performed. Ensuring safety and high quality health care is a permanent feature. When assessing the quality of service, the patient takes into account not only the result of treatment, but also such features as employee interest, safety and respect. A high level of quality of services is possible to achieve thanks to widely developed nursing care, because it is this professional group that most often has the first contact with the patient. When assessing the quality of the service provided, the patient very often assesses it taking into account the nursing staff. Nursing quality refers to acting in accordance with applicable standards and criteria, among others, such as safety, effectiveness, ethics, accessibility and professionalism. Quality assessment is important in shaping the position of a given medical facility on the services market, which is why it is so important to understand the needs of patients.

\section{References}

1. Rutkowska K. Kompetencje społeczne - bufor wypalenia zawodowego pielęgniarek. Medycyna Ogólna i Nauki o Zdrowiu. 2012;18(4):319-323.

2. Juszczak K, Rykowska I. Rola naczelnej pielęgniarki w podnoszeniu jakości usług pielęgniarskich. Pielęgniarstwo Polskie. 2013;3(49):222-229.

3. Błazucka U, Cieślak H. Systemy motywacyjne w pracy pielęgniarki. Pielęgniarstwo Polskie. 2015;57(3):283-287.

4. Scott PA, Matthews A, Kirwan M. What is nursing in the 21 st century and what does the 21st century health system require of nursing? Nursing Philosophy. 2014;15(1): 23-34.

5. Krupienicz A. Podstawy pielęgniarstwa. Repetytorium przedegzaminacyjne. Edra Urban\&Partner;2018.

6. Ustawa z dnia 15 lipca 2011 roku o zawodach pielęgniarki i położnej. Dz.U. 2011 Nr 174, poz.1039.

http://prawo.sejm.gov.pl/isap.nsf/download.xsp/WDU20111741039/U/D20111039Lj.pdf (dostęp: 2020.03.20)

7. Lizak D, Seń M, Laska E. Rola pielęgniarki środowiska nauczania i wychowania w kreowaniu prozdrowotnych postaw uczniów. Pielęgniarstwo XXI wieku. 2012;4:129-133.

8. Ziembicka DM, Marcinowicz L. Pielęgniarska opieka długoterminowa domowa- stan polskich badań naukowych. Family Medicine \& Primary Care Review. 2015;17(3):232-236.

9. Glińska J, Brzezińska E, Lewandowska M, Borowiak E. Rola pielęgnowania w podnoszeniu jakości opieki pielęgniarskiej. Problemy Pielęgniarstwa. 2016;24(3-4): 177-181. 10. Awalkhan A, Muhammad D. Application of Nightingale Nursing Theory to the Care of Patient with Colostomy. European Journal of Clinical and Biomedical Sciences 2016; 2(6): 97-101.

11. D'Antonio P, Beeber L, Sillsc G, Naegled M. The future in the past: Hildegard Peplau and interpersonal relations in nursing. Nursing Inquiry. 2014; 21(4): 311-317. 
12. Ahtisham Y, Jacoline S. Integrating Nursing Theory and Process into Practice; Virginia's Henderson Need Theory. Internation Journal Of Caring Sciences. 2015; 8(2): 443-450.

13. Queirós PJP, Santos Vidinha TS, Almeida Filho AJ. Self-care: Orem's theoretical contribution to the Nursing discipline and profession. Revista de Enfermagem Referência 2014; IV(3):157-163.

14. Kowalik G. Praktyczne zastosowanie modelu pielęgnowania Dorothy Orem. Studia Medyczne. 2012;26(2):107-111

15. Shah M. Compare and Contrast of Grand Theories: Orem's Self-Care Deficit Theory and Roy's Adaptation Model. International Journal of Nursing Didactics. 2015;5(1):39-42.

16. Rosińczuk J, Kołtuniuk A, Górska M, Uchmanowicz I. The Application of Callista Roy Adaptation Model in the Care of Patients with Multiple Sclerosis - Case Report. The Journal of Neurological and Neurosurgical Nursing. 2015;4(3):121-129.

17. Dobocińska Ż. Opieka pielęgniarska - wybrane zagadnienia teoretyczne. Polski Przegląd Nauk o Zdrowiu. 2014;1(38): 59-63.

18. Studnik A, Pierchała A, Wójta-Kempa M. Porównanie wybranych elementów pracy i sytuacji zawodowej pielęgniarek opieki długoterminowej i pielęgniarek środowiskoworodzinnych. Pielęgniarstwo i Zdrowie Publiczne. 2013;3(2):143-153.

19. Raulinajtys-Grzybek M. Zarzadzanie kosztami podmiotów leczniczych. Rola i zadania pielęgniarek. Wolters Kluwer Polska SA;2013.

20. Bembnowska M, Jośko-Ochojska J. Zarządzanie jakością w ochronie zdrowia. Hygeia Public Health. 2015;50(3):457-462.

21. Jha D, Frye AK, Schlimgen J. Evaluating variables of patient experience and the correlation with design. Patient Experience Journal 2017; 4(1): 33-45.

22. Opolski K, Dykowska G, Możdżonek M. Zarządzanie przez jakość w usługach zdrowotnych. Wydawnictwo CeDeWu; 2003.

23. Juszczak K, Rykowska I. Rola naczelnej pielęgniarki w podnoszeniu jakości usług pielęgniarskich. Pielęgniarstwo Polskie. 2013;3(49):219-229.

24. Mehta SJ. Patient Satisfaction Reporting and Its Implications for Patient Care. AMA Journal of Ethics. 2015;17(7):616-21.

25. Pintal-Ślimak M, Eusebio M-O, Pietruczuk M. Jakość w opiece zdrowotnej. Diagnostyka Labolatoryjna. 2018;54(3):197-200.

26. Moczydłowska Alicja, Krajewska-Kułak Elżbieta, Kózka Maria, Bielski Krzysztof, Kulesza-Brończyk Bożena, Kalandyk Halina. Oczekiwania chorych wobec personelu pielęgniarskiego. Problemy Pielęgniarstwa. 2014;22(4):464-470.

27. Hickey JV, Giardino ER. The role of nurses in hospital quality improvement. The Journal of Neurological and Neurosurgical Nursing. 2018;8(1):1-8.

28. Czerw A, Religioni U, Matuszna A, Lesiak K, Olejnik A. Zasady skutecznej komunikacji w placówkach medycznych. Hygeia Public Health. 2012;47(3):247-253.

29. Miller D, Milik A. Komunikacja interpersonalna w zakładach opieki zdrowotnej. Journal of Management and Finanse. 2014;12(2):133-144. 